"Mircea cel Batran" Naval Academy Scientific Bulletin, Volume XIX - 2016 - Issue 1

Published by "Mircea cel Batran" Naval Academy Press, Constanta, Romania // The journal is indexed in:

PROQUEST / DOAJ / DRJI / JOURNAL INDEX / I2OR / SCIENCE LIBRARY INDEX / Google Scholar / Crossref /

Academic Keys / ROAD Open Access / OAJI / Academic Resources / Scientific Indexing Services / SCIPIO

\title{
CYLINDER AND SYSTEM LUBRICATING OILS
}

\author{
Ion Adrian GIRBA ${ }^{1}$ \\ Beazit ALI ${ }^{2}$ \\ Levent ALI \\ Anastase PRUIU \\ ${ }^{1} \mathrm{PhD}$ attendee Eng., Military Technical Academy, Bucharest, Romania \\ 2 Professor PhD Eng., Marine Engineering and Naval Weapons Department, "Mircea cel Bătrân" Naval \\ Academy, Constanţa, Romania \\ ${ }^{3} \mathrm{PhD}$ attendee Eng., Bureau Veritas Romania Controle International, Romania \\ ${ }^{4}$ Professor PhD Eng., Marine Engineering and Naval Weapons Department, "Mircea cel Bătrân" Naval \\ Academy, Constanţa, Romania
}

Abstract: Increased thermal efficiency, savings in the fuel consumption and the possibility to burn low quality fuels conducted to an intense development of marine engines in past 20 years, this progress being emphasized by the increased combustion pressures and better combustion properties. These improvements represent a continuous challenge for lubricating oil manufacturers: the rise in combustion temperatures and pressures is making difficult to preserve the oil film in critical areas and the longer strokes of the piston leads to issues of spreading the oil. Adding here the new type of engines using gas or biofuel which requires different types of lubricating oils. Therefore, the success of new generation of engines will depend on lubricating oils quality.

Keywords: antioxidant additives, lubricating oil, detergent, emulsification.

Lubricating oils are complex mixtures formed by base oils and chemical additives Base oils are derived from refining of specific petroleum products, and their properties such as stability at high temperatures and viscosity depends on the petroleum disposition and manufacturing process. Attainment of the base oil is starting with fractioning of the atmopsheric residue in the steam distillation unit which operates at low pressure and higher tide than other distillation units. In this step, napthenes, aromatic compounds, sulphur and other impurities are removed before the oil is used resulting neutral solvents.

Compared with marine fuels, lubricating oils are using a large number of additives. The quality of lubricating oil as final product depends not only on the base oil properties, but also the response of treatment with additives. Selection of additives is a long process based on predicitions from empirical results and final tests of marine engines. The exact composition of lubricating oils is well known only by manufacturers, however the main characteritics of their additives are familiar:

- Detergents and dispersants are used to clean the engine. Detergents are more efficient on the hot areas of the engines, for exemple the piston head, where can prevent or destroy carbon deposits. Dispersants help maintaining combustion residues suspended in oil until are completely removed via filters or centrifuges.

\section{- Stabilizing additives for high pressures}

which contribiutes at maintaining lubricating process at most severe conditions

\section{- Antioxidant additives that delay}

deterioration due to thermal phenomena and oxidation at high pressures, increasing lifetime of the lubricating oil.

\begin{tabular}{|c|c|c|}
\hline Additive Type & Utilization & $\begin{array}{l}\text { Chemical } \\
\text { Components }\end{array}$ \\
\hline Detergents & $\begin{array}{l}\text { Prevent } \\
\text { formation of } \\
\text { deposits, } \\
\text { neutralise acids } \\
\text { and protect } \\
\text { against } \\
\text { corrosion. }\end{array}$ & 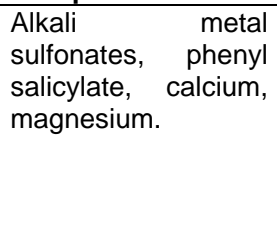 \\
\hline Dispersants & $\begin{array}{l}\text { Overrule water } \\
\text { formation. }\end{array}$ & $\begin{array}{l}\text { Succinimide, ester, } \\
\text { polyisobutylene }\end{array}$ \\
\hline Antioxidants & $\begin{array}{l}\text { Prevent } \\
\text { lubricating oil } \\
\text { oxidation }\end{array}$ & $\begin{array}{l}\text { Aromatic amines, } \\
\text { phenols, zinc } \\
\text { dithiocarbamate, } \\
\text { zinc } \\
\text { dithiophosphate. }\end{array}$ \\
\hline Anti-wear & $\begin{array}{l}\text { Reduce wear by } \\
\text { forming of the oil } \\
\text { film }\end{array}$ & $\begin{array}{l}\text { Zinc } \\
\text { dithiophosphate, } \\
\text { sulfur fatty acid, } \\
\text { sulfide, alkenes } \\
\text { sulfate, zinc } \\
\text { dithiocarbamate }\end{array}$ \\
\hline Antifoaming & $\begin{array}{l}\text { Reduce surface } \\
\text { tensions in order } \\
\text { to prevent } \\
\text { foaming } \\
\text { formation }\end{array}$ & Silicon poliakrilat \\
\hline Corrosion & Prevent rust & Neutral sulphates, \\
\hline
\end{tabular}


"Mircea cel Batran" Naval Academy Scientific Bulletin, Volume XIX - 2016 - Issue 1

Published by "Mircea cel Batran" Naval Academy Press, Constanta, Romania // The journal is indexed in: PROQUEST / DOAJ / DRJI / JOURNAL INDEX / I2OR / SCIENCE LIBRARY INDEX / Google Scholar / Crossref /

Academic Keys I ROAD Open Access / OAJI / Academic Resources / Scientific Indexing Services / SCIPIO

\begin{tabular}{|l|l|l|}
\hline inhibitors & formation & $\begin{array}{l}\text { phosphates, } \\
\text { dispersants }\end{array}$ \\
\hline Emulsifiers & $\begin{array}{l}\text { Prevent water } \\
\text { formation. }\end{array}$ & Ethoxylated alcohols \\
\hline
\end{tabular}

Table 1. Typical additivies incorporated in lubricating oil composition.

For marine engines operating on fossil fuels which contains sulphur, cylinders lubricating is serving to following purposes:

-increasing and maintaining of an oil film in order to prevent metal to metal contact between cylinder liner and piston rings. corrosion -neutralising of sulphuric acid to prevent

-cleaning cylinder liner and pistong rings to prevent failures caused by deposits accumulated during and after combustion.

Lubricating oils used for cylinders lubrication are composed by very good quality base oils together with a a sum of additives which are defining a large variety of functions. The product must possess adequate viscosity at high operating temperatures, to be fluid enough to spread rapidly on the operating surfaces, with good metallic properties and to form an efficient seal between piston rings and the cylinder liner.
Present experience shows that cylinder oils with total base number TBN 70 and viscosity SAE 50 is the most efficient quaility-cost for low speed engines.

Cylinder lubricating oils are essential in wear control of piston rings. High wear rates can be caused by corrosive, abrasive and adhesive wear, prevailing conditions in combustion chamber being the major influence of wear type. Traditionally, cylinder oills have high alkalinity in order to provide protection against corrosive wear. When cylinder liner temperature have reached $250^{\circ} \mathrm{C}$, oil performances become marginal in providing protection against corrosive wear. Under these circumstances, wear type is predominantly adhesive and the oil performances must be analysed to minimize the wear. However, corrosive wear is not a problem completely removed by the type of lubricating oil: theory has shown that engines which are developing high pressures, corrosive wear is noted when more sulphur is converted resulting sulphur trioxide, and if the charge air contains sufficient water, in combination with sulphur trioxide will conduct at sulphuric acid formation at sufficient quantities to start corrosive wear process.

\section{CONCLUSION}

Environmental legislation had also a significant impact on lubricating oils chemical composition. Reducing the sulfur content of fuels affects the total base number and leads to the need of a new balance of detergents and dispersants additives. Measures to reduce NOx emissions from marine engines, such as delayed injection, water injection into the cylinder, fuel emulsification, catalytic reduction systems based on ammonia, also dictates the need to change the detergent, hydrolysis resistance and compatibility with catalysts. All additives are created from a number of ingredients, each performing different functions. A percentage of chemical molecules, eg detergents, cleans the engine and another part neutralizes acids and other combustion products. Additives are interacting with each other, either positive (synergistic) or negative (antagonism). Lubricating oil manufacturer's focus will be mainly on base oil and optimizing additives proportions for each purpose.

\section{BIBLIOGRAPHY}

[1].International Association of Classification Societies, Requirements Concerning Machinery Installations, 2013

[2].Jemmings, Gordon, Two-stroke Tuners Handbook, 2007

[3].Woodyard, Doug, Marine Diesel Engines, 2006

[4].Pruiu Anastase, Instalatii Energetice Navale, 2000

[5].ISO 15550, 2002

[6].Chevron, Marine Lubrication Systems - Stem to Stern, 2002 